\title{
The Clinical Importance of C-Reactive Protein to Albumin Ratio (CAR) in Patients Diagnosed with COVID-19
}

\section{COVID-19 Tanılı Hastalarda C-Reaktif Protein Albumin Oranının (CAR) Klinik Önemi}

\author{
๑iclal Hocanlı', @Mehmet Kabak² \\ 'Mehmet Akif İnan Training And Research Hospital, Department Of Chest Diseases, Şanlıurfa, Turkey \\ ${ }^{2}$ Mardin Public Hospital, Clinic of Chest Diseases, Mardin, Turkey
}

\begin{abstract}
Aim: The course of COVID-19 infection due to SARS-CoV-2 is manifested by viral replication in the upper respiratory tract with or without lung involvement and extrapulmonary systemic hyperinflammation syndrome. Because it has a wide clinical spectrum ranging from asymptomatic cases to multiorgan failure, early identification of prognostic biomarkers is crucial to distinguish patients at risk of developing more serious disease. Our aim is to investigate the relationship between the $\mathrm{C}$-reactive protein to albumin ratio (CAR), a biomarker which has both prognostic and diagnostic importance, and COVID-19 infection
\end{abstract}

Material and Method: Between 1 June 2021 and 1 September 2021, 215 patients who were followed up in the pandemic service and intensive care unit for COVID-19 pneumonia were retrospectively analyzed. The demographic and routine laboratory data of the patients and the parameters accepted as new inflammatory biomarkers such as neutrophil to lymphocyte ratio (NLR), platelet to lymphocyte ratio (PLR) lymphocyte to monocyte ratio (LMR), and CAR were compared between the patient groups in the service and intensive care unit, and the groups of patients who died and were discharged.

Results: A total of 205 patients with a diagnosis of COVID-19 pneumonia, $113(55.1 \%)$ male and 92 (44.9\%) female, were included in the study. When CAR, known as a new inflammatory biomarker, was compared between both groups, it was found to be statistically significantly higher in patients hospitalized in the intensive care unit $(p<0.001)$. In addition, this biomarker was shown to be significantly associated with mortality $(p=0.001)$. The presence of Hypertension (HT) and malignancy was found to be statistically significant in terms of the risk of hospitalization and mortality in the intensive care unit ( $p<0.001, p<0.001$, respectively).

Conclusion: The CAR can be a reliable, inexpensive and easily accessible parameter that can be used both in clinical classification and in determining the prognosis in COVID-19 infection causing the pandemic.

Keywords: C-reactive protein, albumin, CAR, COVID-19, prognosis
Öz

Amaç: SARS-CoV-2'ye bağlı gelişen COVID-19 enfeksiyonun seyri, akciğer tutulumu olan veya olmayan üst solunum yollarında virüs çoğalması ve ekstrapulmoner sistemik hiperinflamasyon sendromu ile kendini gösterir Asemptomatik vakalardan multiorgan yetmezliğine kadar değişen geniş bir klinik yelpazeye sahip olduğundan, prognostik biyobelirteçlerin erken tanımlanması, daha ciddi hastalık geliştirme riski olan hastaları ayırt etmek için çok önemlidir. Amacımız, hem prognostik hemde diagnostik önemi olan C-reaktif protein albumin oranı (CAR) adlı biyobelirtecin, COVID-19 enfeksiyonu ile ilişkisini araştırmaktır.

Gereç ve Yöntem: 1 Haziran 2021-1 Eylül 2021 tarihleri arasında pandemi servisi ve yoğun bakım ünitesinde COVID-19 pnömonisi nedeniyle takip edilmiş 215 hasta retrospektif olarak incelendi. Hastaların demografik ve rutin laboratuvar verileri ile nötrofil lenfosit oranı (NLR), platelet lenfosit oranı (PLR), lenfosit monosit oranı (LMR) ve CAR gibi yeni inflamatuar biyobelirteçler olarak kabul edilen parametreler, servis ve yoğun bakımda yatan hasta grupları ile exitus ve taburcu olan hasta grupları arasında karşılaşııııldı.

Bulgular: Çalışmaya 113 (\% 55.1)'ü erkek, 92 (\% 44.9)'si kadın olmak üzere toplam 205 COVID-19 pnömoni tanılı hasta dahil edildi. Yeni inflamatuar biyobelirteç olarak bilinen CAR, her iki grup arasında karşılaştıııdığında, yoğun bakımda yatan hastalarda istatiksel olarak anlamlı yüksek bulundu $(p<0.001)$ Ayrıca bu biyobelirteçin mortalite ile anlamlı ilişkili olduğu gösterild $(p=0.001)$.Yoğun bakım yatış ve mortalite riski açısından Hipertansiyon $(H T)$ ve malignite varlığı istatiksel olarak anlamlı bulundu (sırasıyla; $p<0.001$, $p<0.001$ ).

Sonuç: CAR, pandemiye neden olan COVID-19 enfeksiyonunda hem klinik sınıflamada hemde prognozu belirlemede kullanılabilecek güvenilir, ucuz ve kolay ulaşılabilir bir parametre olabilir.

Anahtar Kelimeler: C-reaktif protein, albümin, CAR, COVID-19, prognoz

Corresponding (İletişim): İclal Hocanlı, Associate Professor, M.D., Mehmet Akif İnan Training And Research Hospital, Department Of Chest Diseases, Şanlıurfa, Turkey

E-mail (E-posta): iclalhocanli2163@gmail.com

Received (Geliş Tarihi): 31.12.2021 Accepted (Kabul Tarihi): 22.01.2022 


\section{INTRODUCTION}

SARS-CoV-2 was defined as a viral pneumonia agent which was first seen in China on December 31, 2019. ${ }^{[1]}$ This virus, which later spread all over the world, caused a global pandemic. The clinical picture caused by this virus ranges from asymptomatic cases to acute respiratory failure, diffuse intravascular coagulopathy, septic shock and multiorgan failure. ${ }^{[2]}$ Therefore, early identification of prognostic biomarkers is crucial to distinguish patients at risk of developing more serious disease.

The course of viral infection is manifested by viral replication in the upper respiratory tract with or without lung involvement and an extrapulmonary systemic hyperinflammation syndrome. ${ }^{[3]}$ A cytokine storm characterized by significant elevations of interleukin- (IL-) 2, IL-6, tumor necrosis factor-a, C-reactive protein (CRP), ferritin, $d$-dimer, and low level of albumin is observed usually during the advanced stages of infection in patients who develop this abnormal inflammatory response. ${ }^{[4-6]}$

C-reactive protein to albumin ratio (CAR) is a newly defined systemic inflammatory marker that combines both CRP (positive acute phase reactant) and albumin (negative acute phase reactant) levels. In various studies, it has been emphasized that CAR can be a biomarker with both prognostic and diagnostic importance in different diseases, including COVID-19. ${ }^{[7-9]}$ In this study we aimed to investigate the relationship between COVID-19 infection and CAR and make a scientific contribution to the studies on this topic.

\section{MATERIAL AND METHOD}

Ethics committee approval for this study was obtained for this study (Approval Number: HRU/21.10.18 and Approval Date: 24.05.2021). A written informed consent was obtained from each participant. The study was conducted in accordance with the principles of the Declaration of Helsinki.

215 patients, who were followed up in the pandemic service and intensive care unit for COVID-19 pneumonia between 1 June 2021 and 1 September 2021, were retrospectively analyzed. Patients over the age of 18 , patients with pneumonic infiltration on chest X-ray or Chest computed tomography $(\mathrm{CT})$, patients without evidence of active inflammation due to different organs, patients with biochemical and hematological blood tests taken before treatment on the first day of hospitalization, and patients with positive COVID-19 PCR result were included in this study. Patients under the age of 18 , patients without radiological pneumonic infiltration, and patients without laboratory data on the first day of hospitalization (ten patients) were not included in the study. In the end, a total of two hundred and five (205) patients were included in this study. Demographic and laboratory information of the patients were obtained from the recorded data. Age, gender, comorbidities, hospitalization location, clinical status after treatment, biochemical and hematological laboratory data of all patients were recorded. While 27 patients given 10$15 \mathrm{It} / \mathrm{min} \mathrm{O}_{2}$ with a reservoir (non-rebreathing) mask, with oxygen saturation $\left(\mathrm{SO}_{2}\right)<90 \%$, respiratory rate/min $>30$ and/ or bilateral diffuse infiltration in Chest $\mathrm{CT}$ were followed in the intensive care unit, the remaining 178 patients were followed up in the service. Patients were divided into two groups according to the location of hospitalization as service and intensive care unit. Complete blood count was evaluated with an automated blood cell counter (Coulter LH, 780 Hematology Analyzer, Beckman Coulter Corp, Hileh, Florida) and the ratio of neutrophil to lymphocyte count was calculated as NLR, the ratio of lymphocyte to monocyte count was calculated as LMR, and the ratio of platelet to lymphocyte count was calculated as PLR. The level of albumin and CRP was measured using the Roche Diagonistics Cobas 8000 c502 analyzer and CAR $(\mathrm{mg} / \mathrm{g})$ was calculated as the ratio of CRP to level of albumin. Demographic and routine laboratory data and parameters accepted as new inflammatory biomarkers such as NLR, PLR, LMR and CAR were compared between two groups. Besides, the patients were divided into two different groups, as discharged and exitus, according to their clinical status. Laboratory data and comorbidities were compared to determine the mortality risk.

\section{Statistical Analysis}

Descriptive statistics are presented as mean \pm standard deviation or median (25-75 quartile range). The KolmogorovSmirnov test was used to determine whether the data were normally distributed. Student's $t$ test was used to compare normally distributed data, and Mann-Whitney $\mathrm{U}$ test was used to compare not normally distributed data. Cut-off values were determined using ROC curve analysis to predict ICU admission and mortality according to level of CAR. Statistical significance level was accepted as $p<0.05$.

\section{RESULTS}

A total of 205 patients, including 113 (55.1\%) male and 92 (44.9\%) female patients, with a diagnosis of COVID-19 pneumonia were included in the study. While $86.8 \%$ (178) of these patients were followed in the service, $13.2 \%$ (27) were followed in the intensive care unit. 184 patients were discharged with recovery and 21 patients died.

Demographic and laboratory data of the patients are shown in Table 1. All data were compared between two groups. Compared to those followed in the service, patients followed in the intensive care unit had a statistically significant higher male sex ratio and the age $(p=0.003, p=0.008$, respectively). There were statistical differences in serum albumin, CRP, White blood cell $(W B C)$, neutrophil, lymphocyte, lactate dehydrogenase $(\mathrm{LDH})$, aspartate aminotransferase (AST) values between two groups. Lymphopenia, hypoalbuminemia, leukocytosis, and the high level of NLR and PLR were more significant in patients who were followed in the intensive care unit. 
When CAR, known as the new inflammatory biomarker, was compared between two groups, it was found to be statistically significantly higher in patients hospitalized in the intensive care unit $(p<0.001)$ (Table 1). Besides, a significant relationship was shown between this biomarker and mortality (Table 2).

\begin{tabular}{|c|c|c|c|}
\hline & $\begin{array}{l}\text { Service } \\
(n=178)\end{array}$ & $\begin{array}{c}\text { Intense care unit } \\
(\mathbf{n}=\mathbf{2 7})\end{array}$ & $\mathbf{P}$ \\
\hline Age, years & $53.5(34.7-87.0)$ & $73.0(63.0-84.0)$ & 0.008 \\
\hline Gender, F/M & $87 / 91$ & $5 / 22$ & 0.003 \\
\hline Urea, mg/dl & $29.9(23.5-39.4)$ & $78.0(35.3-100.0)$ & $<0.001$ \\
\hline Creatine, $\mathrm{mg} / \mathrm{dl}$ & $0.7(0.8-1.0)$ & $0.9(0.8-1.8)$ & 0.001 \\
\hline Albumin, mg/dl & $4.2 \pm 0.5$ & $3.4 \pm 0.5$ & $<0.001$ \\
\hline AST, U/dL & $29.0(24.0-38.7)$ & $44.0(25.0-63.0)$ & 0.028 \\
\hline $\mathrm{ALT}, \mathrm{U} / \mathrm{dL}$ & $27.0(20.0-38.2)$ & $29.0(18.0-53.0)$ & 0.975 \\
\hline $\mathrm{LDH}, \mathrm{U} / \mathrm{L}$ & $239.5(188.0-309.7)$ & $385.0(188.0-563.0)$ & 0.021 \\
\hline Sodium, mg/dl & $138.9 \pm 3.8$ & $138.7 \pm 7.4$ & 0.873 \\
\hline Potassium, mg/dl & $4.1 \pm 0.7$ & $4.3 \pm 0.9$ & 0.101 \\
\hline CRP, mg/dl & $9.2(2.7-45.0)$ & $59.9(48.1-131.7)$ & $<0.001$ \\
\hline $\mathrm{WBC}, \times 10^{3} / \mathrm{mL}$ & $5.6(4.5-7.8)$ & $9.2(5.0-12.0)$ & 0.005 \\
\hline Neutrophil, $\times 10^{3} / \mathrm{mL}$ & $3.5(2.5-5.4)$ & $7.9(3.9-10.2)$ & $<0.001$ \\
\hline Lymphocyte, $\times 10^{3} / \mathrm{mL}$ & $1.4(0.8-1.9)$ & $0.6(0.5-1.1)$ & $<0.001$ \\
\hline Monocyte, $\times 10^{3} / \mathrm{mL}$ & $0.5(0.3-0.6)$ & $0.6(0.2-0.7)$ & 0.902 \\
\hline Platelet, $\times 10^{3} / \mathrm{mL}$ & $205.5(170.2-256.7)$ & $166.0(131.0-307.0)$ & 0.239 \\
\hline$M C V, f L$ & $79.2 \pm 16.3$ & $85.3 \pm 7.5$ & 0.136 \\
\hline$M P V, f L$ & $10.4(9.6-11.0)$ & $10.5(10.0-11.0)$ & 0.334 \\
\hline RDW, \% & $12.8(12.2-13.7)$ & $18.6(12.9-47.6)$ & $<0.001$ \\
\hline NLR & $2.6(1.6-4.8)$ & $10.2(3.8-15.8)$ & $<0.001$ \\
\hline PLR & $155.7(105.1-214.5)$ & $284.1(138.3-472.9)$ & $<0.001$ \\
\hline LMR & $2.5(1.6-3.9)$ & $1.6(1.0-4.0)$ & 0.115 \\
\hline CAR & $2.1(0.6-11.0)$ & $20.3(13.3-38.7)$ & $<0.001$ \\
\hline
\end{tabular}

ALT, alanine aminotransferase; AST, aspartate aminotransferase; $L D H$, lactat dehydrogenase; CRP, C-reactive protein; WBC, white blood cell: MCV, mean corpuscular volume; MPV, mean platele

lymphocyte ratio; LMR, lymphocyte to monocyte ratio; CAR, C reactive protein to albumin ratio.

Table 2. Comparison of laboratory data according to clinical status after treatment

\begin{tabular}{|c|c|c|c|}
\hline & Discharged $(n=184)$ & Exitus $(n=21)$ & $\mathbf{P}$ \\
\hline Urea, mg/dl & $31.0(21.5-40.2)$ & 87.7 (64.2-106.5) & $<0.001$ \\
\hline Creatine, mg/dl & $0.8(0.7-1.0)$ & $1.2(0.8-1.2)$ & $<0.001$ \\
\hline Albumin, mg/dl & $4.2 \pm 0.5$ & $3.3 \pm 0.3$ & $<0.001$ \\
\hline AST, U/dL & $29.0(24.0-34.0)$ & $37.0(20.5-64.0)$ & 0.178 \\
\hline ALT, U/dL & $27.0(20.0-37.5)$ & $26.8(15.0-15.0)$ & 0.513 \\
\hline LDH, U/L & $241.0(188.0-316.2)$ & $303.0(11.0-612.5)$ & 0.200 \\
\hline Sodium, mg/dl & $138.7 \pm 3.8$ & $140.0 \pm 7.9$ & 0.490 \\
\hline Potassium, mg/dl & $4.1 \pm 0.7$ & $4.4 \pm 1.0$ & 0.034 \\
\hline CRP, mg/dl & $10.0(2.9-49.7)$ & $86.5(49.5-179.5)$ & $<0.001$ \\
\hline $\mathrm{WBC}, \times 10^{3} / \mathrm{mL}$ & $5.6(4.4-7.4)$ & $11.0(6.5-13.7)$ & $<0.001$ \\
\hline Neutrophil, $\times 10^{3} / \mathrm{mL}$ & $3.5(2.5-5.2)$ & $9.9(5.4-10.9)$ & $<0.001$ \\
\hline Lymphocyte, $\times 10^{3} / \mathrm{mL}$ & $1.3(0.8-1.9)$ & $0.6(0.4-1.0)$ & $<0.001$ \\
\hline Monocyte, $\times 10^{3} / \mathrm{mL}$ & $0.4(0.3-0.6)$ & $0.6(0.2-0.7)$ & 0.921 \\
\hline Platelet, $\times 10^{3} / \mathrm{mL}$ & $205.0(169.0-256.2)$ & $227.0(137.5-317.0)$ & 0.986 \\
\hline $\mathrm{MCV}, \mathrm{fL}$ & $79.4 \pm 16.4$ & $85.3 \pm 7.5$ & 0.155 \\
\hline MPV, fL & $10.4(9.7-11.0)$ & $10.5(10.0-11.0)$ & 0.372 \\
\hline RDW, \% & $12.8(12.2-13.7)$ & $41.1(13.1-48.7)$ & $<0.001$ \\
\hline NLR & $2.7(1.6-4.8)$ & $12.7(7.0-20.8)$ & 0.001 \\
\hline PLR & 155.7 (105.1-217.8) & 335.0 (172.9-548.4) & 0.001 \\
\hline LMR & $2.5(1.6-3.9)$ & $1.6(1.0-4.0)$ & 0.109 \\
\hline CAR & $2.2(0.6-11.7)$ & $22.7(13.7-57.4)$ & 0.001 \\
\hline \multicolumn{4}{|c|}{$\begin{array}{l}\text { ALT, alanine aminotransferase; AST, aspartate aminotransferase; LDH, lactat dehydrogenase; CRP, } \\
\text { C-reactive protein; WBC, white blood cell; MCV, mean corpuscular volume; MPV, mean platelet } \\
\text { volume; RDW, red cell distribution width; NLR, Neutrophil to lymphocyte ratio; PLR, platelet to } \\
\text { lymphocyte ratio; LMR, lymphocyte to monocyte ratio; CAR, C reactive protein to albumin ratio. }\end{array}$} \\
\hline
\end{tabular}

The comorbidities of the patients included in the study are shown in Table 3. Presence of hypertension (HT) and malignancy were found to be statistically significant factors in terms of hospitalization at intensive care unit and mortality.

Table 3. Comparison of comorbidities with hospitalization and mortality status

\begin{tabular}{lcccccc} 
& DM & HT & CAD & Asthma & COPD & Malignancy \\
\hline $\begin{array}{l}\text { Patient location } \\
\text { Service }(n=178)\end{array}$ & 17 & 14 & 8 & 7 & 3 & 0 \\
$\begin{array}{l}\text { Intensive care unit } \\
(\mathrm{n}=27)\end{array}$ & 4 & 8 & 2 & 1 & 2 & 2 \\
$\mathrm{P}$ & 0.401 & 0.001 & 0.513 & 0.954 & 0.072 & $<0.001$ \\
Mortality status & & & & & & \\
$\quad$ Discharge ( $\mathrm{n}=184)$ & 17 & 14 & 8 & 7 & 3 & 0 \\
Exitus ( $\mathrm{n}=21)$ & 4 & 8 & 2 & 1 & 2 & 2 \\
$P$ & 0.160 & $<0.001$ & 0.297 & 0.830 & 0.026 & $<0.001$ \\
\hline
\end{tabular}

DM; Diabetes Mellitus, HT; Hypertension, CAD; Coronary Artery Disease, COPD; Chronic Obstructive Pulmonary Disease

ROC curve analysis was performed to determine the cut-off values of CAR in predicting the hospitalization at intensive care unit and mortality. The optimal cut-off value of CAR for intensive care admission was determined as $\geq 12.6 \%$ with a sensitivity of $81 \%$ and a specificity of $79 \%$ (Figure 1). On the other hand, the optimal cut-off value of CAR for mortality was found as $\geq 13.9$ with a sensitivity and specificity of $76 \%$ and 81 , respectively (Figure 2 ).

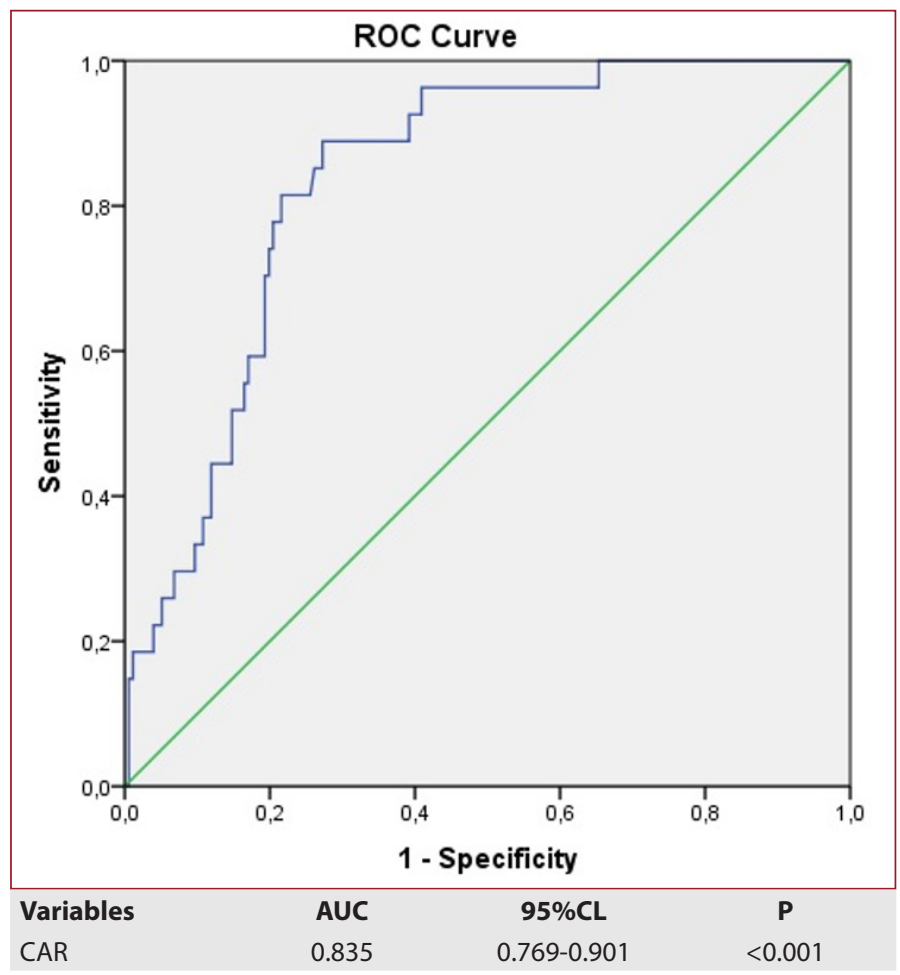

Figure 1. ROC curve of CAR level for predicting ICU admissions 


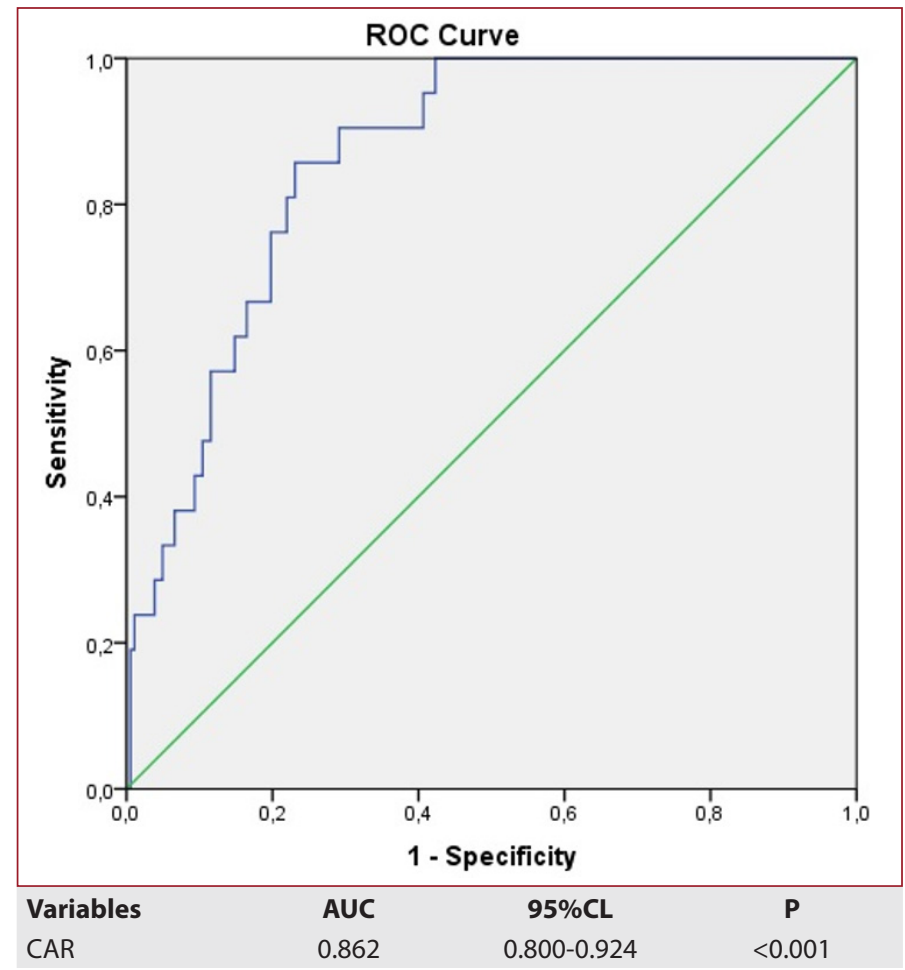

Figure 2. ROC curve of CAR levels for predicting mortality

\section{DISCUSSION}

As a result of our study, we found that CAR is a significant prognostic parameter in estimating the risk of intensive care unit admission and mortality due to COVID-19 infection, and that HT and malignancy are important comorbidities that affect the prognosis.

The clinical manifestation of COVID-19 infection is generally mild. However, patients may sometimes rapidly develop an acute respiratory failure, diffuse intravascular coagulopathy, septic shock which may result in mortality. Age, gender, and comorbidities (HT, Diabetes mellitus (DM), Coronary Arterial Disease (CAD), chronic lung diseases, malignancies, etc.) are among the most important factors affecting the prognosis in COVID-19 patients. In many studies, advanced age and male gender predominance and accompanying comorbidities such as DM, HT, CAD, and malignancy have been observed in patients with severe PCR (+) COVID-19 diagnosis. ${ }^{[10-13]}$ Similar to the literature data, the patients followed in the intensive care unit were older and mostly male in our study and the mortality risk was statistically significantly higher, especially in those with a history of HT and malignancy.

Hematological and biochemical parameters are of great importance in the evaluation of clinical picture of patients with COVID-19 diagnosis. While the severity of patient clinic is generally in a positive correlation with increases in leukocyte and neutrophil counts, and the level of LDH, AST, and alanine aminotransferase (ALT); it has been observed that there is a negative correlation with a decrease in lymphocyte and eosinophil counts. ${ }^{[11,14]}$ In our current study, we found a significant difference in terms of leukocytosis, neutrophilia, lymphopenia, high LDH and AST levels in patients followedup in the intensive care unit compared to those hospitalized in the service.

CRP has been used as a systemic marker for tissue damage, infection, and inflammation since it was first defined as an acute phase protein. ${ }^{[15]}$ Various studies reported that the level of CRP is an independent predictor for severe COVID-19 infection, malignancies, neurological and cardiac diseases. ${ }^{[16-19]}$ The concentration of albumin is negatively related to systemic inflammatory response which is caused by down-regulation of hepatic synthesis due to the increased catabolism and cytokines such as TNF-a. ${ }^{[20]}$ Systemic inflammation due to viral infections, including COVID-19 infection, might cause a decrease in the level of albumin. In a recent study, low serum albumin levels were found to be significantly related with worsened clinical status and longer hospital stay in COVID-19 patients. ${ }^{[2]]}$ However, albumin might not be a specific parameter alone in determining the inflammation since low albumin levels may develop due to reasons such as advanced age and nutritional deficiencies. In our study, we found that high CRP and low albumin levels were statistically significant in patients who were followed in the intensive care unit and were exitus. We think that the CRP and albumin levels of the patients are important in terms of determining inflammation, since these are the results of the examinations obtained within the first 24 hours of hospitalization.

The scientific community is in urgent need of reliable, new biomarkers of COVID-19 disease progression to classify high-risk patients. The CRP to albumin ratio (CAR), which is considered as a new inflammatory biomarker, reflects the balanced relationship between the severity of inflammatory reactions and immune status more accurately. In literature, it has been stated that CAR is an important biomarker that can be used in clinical follow-up and prognosis prediction for different malignancies, cardiac, neurological, and systemic inflammatory diseases. ${ }^{[22-25]}$ In recent studies, it has been emphasized that CAR may be a promising prognostic biomarker for risk stratification and clinical management of patients with severe COVID-19 and can be an early predictor of disease progression. ${ }^{[26,27]}$ In this study, we assumed that CAR alone can be a stronger prognostic parameter than CRP and albumin in predicting clinical severity and mortality in hospitalized patients with a diagnosis of COVID 19. We determined that the level of serum CAR, both in patients who are hospitalized in the intensive care unit and who died after treatment due to COVID-19 infection, was significantly higher than patients who were followed-up in service and who were alive. Besides, we predicted the risk of hospitalization and death in the intensive care unit in ROC analysis with high sensitivity and specificity in the presence of increased CAR levels in patients with a diagnosis of COVID-19.

The limitations of this study include its single-center and retrospective design, exclusion of patients with mild clinical course with $\mathrm{PCR}(+)$ and no lung involvement on Chest $\mathrm{CT}$ 
due to hospitalization and lack of recorded laboratory data, and inclusion of patients with malignancies and chronic comorbidities that may affect the inflammatory response.

\section{CONCLUSION}

The CAR is a new biomarker that has been widely used because of its diagnostic and prognostic importance in different clinical pathologies. We can conclude that this biomarker is a reliable, inexpensive, and easily accessible parameter that can be used to determine the clinical classification and prognosis of COVID-19 infection.

\section{ETHICAL DECLARATIONS}

Ethics Committee Approval: Ethics committee approval for this study was obtained from the Dean of Harran University Faculty of Medicine (Approval Number: HRU/21.10.18 and Approval Date: 24.05.2021).

Informed Consent: Because the study was designed retrospectively, no written informed consent form was obtained from patients.

Referee Evaluation Process: Externally peer-reviewed.

Conflict of Interest Statement: The authors have no conflicts of interest to declare.

Financial Disclosure: The authors declared that this study has received no financial support.

Author Contributions: All of the authors declare that they have all participated in the design, execution, and analysis of the paper, and that they have approved the final version.

\section{REFERENCES}

1. Wang C, Horby PW, Hayden FG, Gao GF. A novel coronavirus outbreak of global health concern. Lancet 2020;395(10223):470-3.

2. Görlinger K, Dirkmann D, Gandhi A, Simioni P. COVID-19-Associated Coagulopathy and Inflammatory Response: What Do We Know Already and What Are the Knowledge Gaps? Anesth Analg 2020;131(5):1324-33.

3. Siddiqu HK, Mehra MR. COVID-19 illness in native and immunosuppressed states: a clinical therapeutic staging proposal. J Heart Lung Transplant 2020;39(5):405-7.

4. Tan C, Huang Y, Shi F, et al. C-reactive protein correlates with computed tomographic findings and predicts severe COVID-19 early. J Med Virol 2020;92(7):856-62.

5. Huang W, Li C, Wang Z, et al. Decreased serum albumin level indicates poor prognosis of COVID-19 patients: hepatic injury analysis from 2,623 hospitalized cases. Sci China Life Sci 2020;63(11):1678-87.

6. Huang J, Cheng A, Kumar R, et al. Hypoalbuminemia predicts the outcome of COVID-19 independent of age and co-morbidity. J Med Virol 2020;92(10):2152-8.

7. Liu Y, Chen S, Zheng $C$, et al. The prognostic value of the preoperative c-reactive protein/albumin ratio in ovarian cancer. BMC Cancer 2017;17(1):285.

8. Karabağ Y, Çağdaş $M$, Rencuzogullari I, et al. Relationship between $\mathrm{C}$-reactive protein/albumin ratio and coronary artery disease severity in patients with stable angina pectoris. J Clin Lab Anal 2018;32(7):e22457.

9. Kalyon S, Gültop F, Şimşek F, Adaş M. Relationships of the neutrophillymphocyte and CRP-albumin ratios with the duration of hospitalization and fatality in geriatric patients with COVID-19. J Int Med Res 2021;49(9):3000605211046112.
10. Alharthy A, Aletreby W, Faqihi F, et al. Clinical Characteristics and Predictors of 28-Day Mortality in 352 Critically III Patients with COVID-19: A Retrospective Study. J Epidemiol Glob Health 2021;11(1):98-104.

11. Chen N, Zhou M, Dong X, et al. Epidemiological and clinical characteristics of 99 cases of 2019 novel coronavirus pneumonia in Wuhan, China: a descriptive study. Lancet 2020;395(10223):507-13.

12. Jibrin YB, Okwong OK, Maigari IM, et al. Clinical and laboratory characteristics of COVID-19 among adult patients admitted to the isolation centre at Abubakar Tafawa Balewa Teaching Hospital Bauchi, Northeast Nigeria. Pan Afr Med J 2020;37(Suppl 1):27.

13. Huang $R$, Zhu $L$, Xue $L$, et al. Clinical findings of patients with coronavirus disease 2019 in Jiangsu province, China: A retrospective, multi-center study. PLoS Negl Trop Dis 2020;14(5):e0008280.

14. Lippi G, Plebani M. The critical role of laboratory medicine during coronavirus disease 2019 (COVID-19) and other viral outbreaks. Clin Chem Lab Med 2020;58(7):1063-9.

15. Pepys MB, Hirschfield GM. C-reactive protein: a critical update. J Clin Investig 2003;111(12):1805-12.

16. Morimoto M, Honjo S, Sakamoto T, et al. Prognostic Impact of Pre- and Post-operative P-CRP Levels in Pancreatic Cancer Patients. Yonago Acta Med 2020;63(1):70-8.

17. Sharifpour M, Rangaraju S, Liu M, et al; Emory COVID-19 Quality \& Clinical Research Collaborative. C-Reactive protein as a prognostic indicator in hospitalized patients with COVID-19. PLoS One 2020;15(11):e0242400.

18. Geenen LW, Baggen VJM, van den Bosch AE, et al. Prognostic value of C-reactive protein in adults with congenital heart disease. Heart 2020;107(6):474-81.

19. Lunetta C, Lizio A, Maestri E, et al. Serum C-Reactive Protein as a Prognostic Biomarker in Amyotrophic Lateral Sclerosis. JAMA Neurol 2017;74(6):6607.

20. Chojkier M. Inhibition of albumin synthesis in chronic diseases: molecular mechanisms. J Clin Gastroenterol 2005;39(4 Suppl 2):143-6.

21. Li J, Li M, Zheng S, et al. Plasma albumin levels predict risk for nonsurvivors in critically ill patients with COVID-19. Biomark Med 2020;14(10):827-37.

22. Deng TB, Zhang J, Zhou YZ, Li WM. The prognostic value of C-reactive protein to albumin ratio in patients with lung cancer. Medicine (Baltimore) 2018;97(50):e13505.

23. Söğüt Ö, Akdemir T, Can MM. Prognostic value of the C-reactive protein to albumin ratio in patients undergoing primary percutaneous coronary intervention for ST-segment elevation myocardial infarction. Turk J Med Sci 2021;51(3):1281-8.

24. Cayir S, Hizli O, Kayabasi S. Is C-reactive protein to albumin ratio an indicator of poor prognosis in Bell's palsy? Eur Arch Otorhinolaryngol 2020;277(1):115-9.

25. Yang WM, Zhang $W H$, Ying $H Q$, et al. Two new inflammatory markers associated with disease activity score-28 in patients with rheumatoid arthritis: Albumin to fibrinogen ratio and C-reactive protein to albumin ratio. Int Immunopharmacol 2018;62:293-8.

26. Kalabin A, Mani VR, Valdivieso SC, Donaldson B. Does C reactive protein/ Albumin ratio have prognostic value in patients with COVID-19. J Infect Dev Ctries 2021;1(8):1086-93.

27. Karakoyun I, Colak A, Turken M, et al. Diagnostic utility of C-reactive protein to albumin ratio as an early warning sign in hospitalized severe COVID-19 patients. Int Immunopharmacol 2021;91:107285. 